\title{
EFFECT OF TYPE OF LEACHATE ON SELF-HEALING CAPACITY OF GEOSYNTHETIC CLAY LINER
}

\author{
Jinchun $\mathrm{CHAI}^{1}$, Kartika SARI ${ }^{2}$ and Takenori $\mathrm{HINO}^{3}$ \\ The effect of type of leachate (liquid) on self-healing capacity of the geosynthetic clay liners (GCLs) has been \\ investigated by laboratory leakage rate tests. Four types of liquids, namely, tap water, $10 \mathrm{~g} / \mathrm{l} \mathrm{NaCl}$ solution, $100 \mathrm{ml} / \mathrm{l}$ \\ ethanol solution and $11.1 \mathrm{~g} / \mathrm{l} \mathrm{CaCl} \mathrm{Cl}_{2}$ solution were used. The test results indicate that the types of liquid have a significant \\ effect on self-healing capacity of GCLs through the influence on the amount of hydration induced expansion of the \\ bentonite inside GCLs. Free swelling index of the bentonite with the corresponding liquid can be used to evaluate the \\ relative effect of the liquid. Also, for the conditions investigated, it seems that overburden stress $(\sigma)$ on the GCL \\ samples does not change the general tendency of the effect of the types of liquid.
}

Keywords: Geosynthetic clay liner, self-healing capacity, leakage rate test, type of leachate, landfill liner

\section{Introduction}

Geosynthetic clay liners (GCLs) are widely used as liquid retaining liners in geotechnical and geoenvironmental engineering ${ }^{1,2,3,4)}$. However, GCLs can be easily damaged during installation process and the joints between GCL panels may form weaker zones. For example, Nosko and Touze-Foltz ${ }^{5)}$ reported an average defect density of 12.9/ha for a surveyed area of about 325 ha.

It is generally believed that GCLs have self-healing capacity owing to the expansion of bentonite, which is a main component of GCLs ${ }^{4,6,7)}$. There are numerous literatures which investigated the effect of types of liquid on hydraulic conductivity of GCL or bentonite ${ }^{4,6-12)}$, but the effect of types of liquid on self-healing capacity of GCL is not well investigated. Further, there are two types of GCLs used in engineering practice, namely geomembrane supported GCL (GM-GCL) and geotextile encased GCL (GT-GCL). Due to the different structures, their self-healing capacity and main influential factors may be different. However, most test results in literature on the self-healing capacity of GCLs are for GT-GCL and there are only few results about GM-GCL ${ }^{13)}$. In this study, effect of types of liquid on self-healing capacities of both GM-GCL and GT-GCL are investigated by a series of laboratory leakage rate tests under both constant head and falling head conditions.

\section{Materials and their properties}

\section{(1) GCLs}

One GT-GCL and one GM-GCL are tested. The GM-GCL consists of a $4 \mathrm{~mm}$-thick of granular bentonite layer glued onto a $0.5 \mathrm{~mm}$ thick of high density polyethyelene geomembrane (HDPE). The GT-GCL consists of granular bentonite powders encased by geotextiles, i.e. a nonwoven geotextile as "cover" and a woven geotextile as "carrier". The two layers of geotextile are connected by needle punched fibers with pitches of $3 \mathrm{~mm} \times 4.5 \mathrm{~mm}$ and thermal treatment. The weight of the GM-GCL and the GT-GCL are about 53 and $49 \mathrm{~N} / \mathrm{m}^{2}$ respectively. The same type of bentonite was used in both of the GM-GCL and the GT-GCL. The bentonites used by the manufacturer are from two locations and their chemical compositions are listed in Table 1.

\section{(2) Liquids}

Tap-water, $10 \mathrm{~g} / \mathrm{l}$ of $\mathrm{NaCl}$ solution, $100 \mathrm{ml} / \mathrm{l}$ of ethanol solution and $11.1 \mathrm{~g} / \mathrm{l}$ of $\mathrm{CaCl}_{2}$ solution were used as liquids in the tests. Values of $\mathrm{pH}$ and electric conductivity of the liquids are given in Table 2.

\section{(3) Interaction behavior of the bentonite and the liquids}

The liquid limit $\left(w_{\mathrm{L}}\right)$ and plastic limit $\left(w_{\mathrm{p}}\right)$ of the bentonite with four types of liquid were measured per JIS A 1205, and free swelling index per ASTM D 5890. The results are summarized in Table 2 also.

Table 1. Chemical composition of the bentonite from $\mathrm{X}$-ray semi-quantitative analysis (The data are provided by the manufacturer)

\begin{tabular}{|c|c|c|}
\hline Chemical composition & \multicolumn{2}{|c|}{$\mathrm{Wt}(\%)$} \\
\cline { 2 - 3 } & Colony & Lovell $^{\mathrm{a}}$ \\
\hline Quartz & 5 & 2 \\
Potassium feldspar & Trace & --- \\
Plagioclase feldspar & Trace & 4 \\
Calcite & ---- & Trace \\
Opal & 2 & 5 \\
Clinoptilolite & ---- & Trace \\
Dioctahedralsmectite & 91 & 85 \\
Illite & 2 & 4 \\
\hline
\end{tabular}

( ${ }^{\mathrm{S} S a m p l e d}$ from Colony and Lovell at Wyoming, USA)

\footnotetext{
${ }^{1}$ Member of IGS, Prof., Saga University, Graduate School of Science and Engineering (

${ }^{2}$ Member of JGS, Post Dr. Researcher, Saga University, Graduate School of Science and Engineering ( 7 840-8502 Saga-shi, Honjo 1)

${ }^{3}$ Member of IGS, Prof., Saga University, Institute of Lowland Technology ( ₹ 840-8502 Saga-shi, Honjo 1)
} 
Table 2. Properties of liquids and interact properties of the liquids and the bentonite

\begin{tabular}{|c|c|c|c|c|c|}
\hline $\begin{array}{c}\text { Types of } \\
\text { liquid }\end{array}$ & $\mathrm{pH}$ & $\begin{array}{c}E C \\
(\mu \mathrm{S} / \mathrm{cm})\end{array}$ & $\begin{array}{c}w_{\mathrm{L}} \\
(\%)\end{array}$ & $\begin{array}{c}w_{\mathrm{p}} \\
(\%)\end{array}$ & $\begin{array}{c}\text { Swelling } \\
\text { index } \\
(\mathrm{ml} / 2 \mathrm{gr})\end{array}$ \\
\hline $\begin{array}{c}\text { Tap water } \\
\text { Ethanol }\end{array}$ & 7.02 & 105 & 537 & 45.8 & 21.5 \\
$\mathrm{NaCl}$ & 7.24 & 17600 & 235 & 46.3 & 16.5 \\
$\mathrm{CaCl}_{2}$ & 7.60 & 199 & 165 & & 9 \\
\hline
\end{tabular}

Following the procedure of Method-C of ASTM D 4546-96, swelling pressures of the bentonite were tested using an oedometer device. Initial water content of the bentonite was adjusted to about $30 \%-100 \%$ and put into a mold of $60 \mathrm{~mm}$ in diameter and $20 \mathrm{~mm}$ in height. Apply a vertical pressure of $300 \mathrm{kPa}$ for 2 hours to compress the sample. The resulting sample had a dry density of $760 \mathrm{~kg} / \mathrm{m}^{3}-1,020 \mathrm{~kg} / \mathrm{m}^{3}$. Then the sample was cut into $5 \mathrm{~mm}$ in thickness and reset into the equipment for swelling pressure test. The tests were conducted with constant volume condition and liquid was supplied until there was no more pressure change. Swelling pressure versus final water content of the samples is presented in Fig. 1. The result shows that the tap-water and the ethanol solution have about the same swelling pressure, but the $\mathrm{NaCl}$ solution has much lower swelling pressure when compared under the same water content condition.

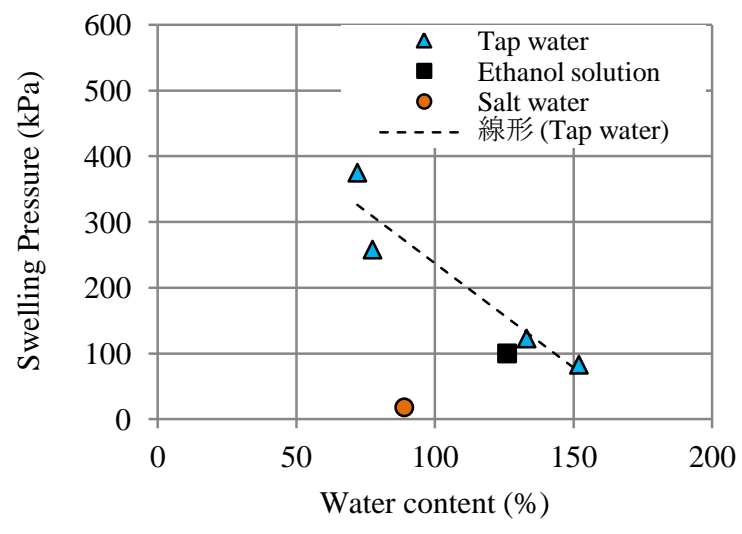

Fig. 1 Swelling pressure of bentonite versus water content

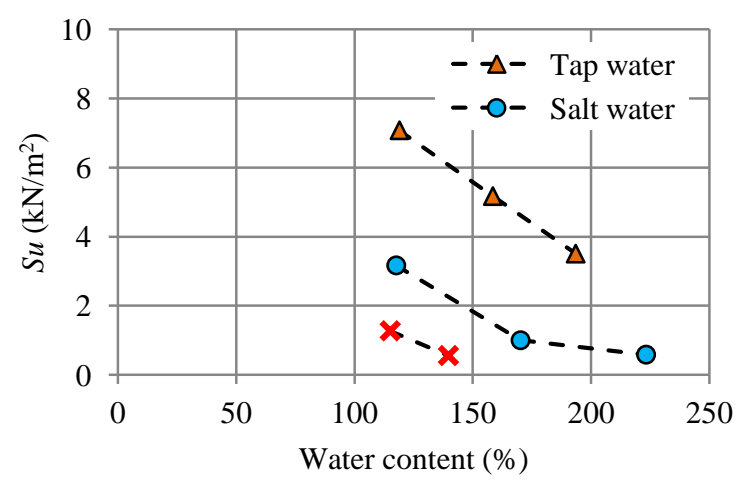

Fig. 2 Undrained shear strength of bentonite versus water content

(4) Undrained shear strength $\left(S_{u}\right)$ of the bentonite

Fundamentally, the self-healing of GCL is the expansion of bentonite into a damage hole and/or squeezing of hydrated bentonite into the hole by overburden pressure. Undrained shear strength $\left(S_{u}\right)$ value is a key parameter affecting the squeezing effect. $S_{u}$ values of the bentonite with different water content of using the tap-water, the $\mathrm{NaCl}$ and $\mathrm{CaCl}_{2}$ solutions were measured by a laboratory vane shear device and the results are shown in Fig. 2. The blade of the vane has a diameter of $20 \mathrm{~mm}$ and height of $40 \mathrm{~mm}$. It can be seen that under the same water content condition, $S_{u}$ values of using the $\mathrm{NaCl}$ and $\mathrm{CaCl}_{2}$ solutions are lower. This is because the bentonite with the $\mathrm{NaCl}$ and $\mathrm{CaCl}_{2}$ solutions has lower $w_{\mathrm{L}}$ values as indicated in Table 2. At a water content of about $200 \%$, it is close to $w_{\mathrm{L}}$ value for the $\mathrm{NaCl}$ solution, but it is only about $1 / 3$ of $w_{\mathrm{L}}$ value of the tap-water case.

\section{Leakage rate tests and results}

Both constant head and falling head devices were used to accelerate the test program and provide a cross check on the reliability of test results.

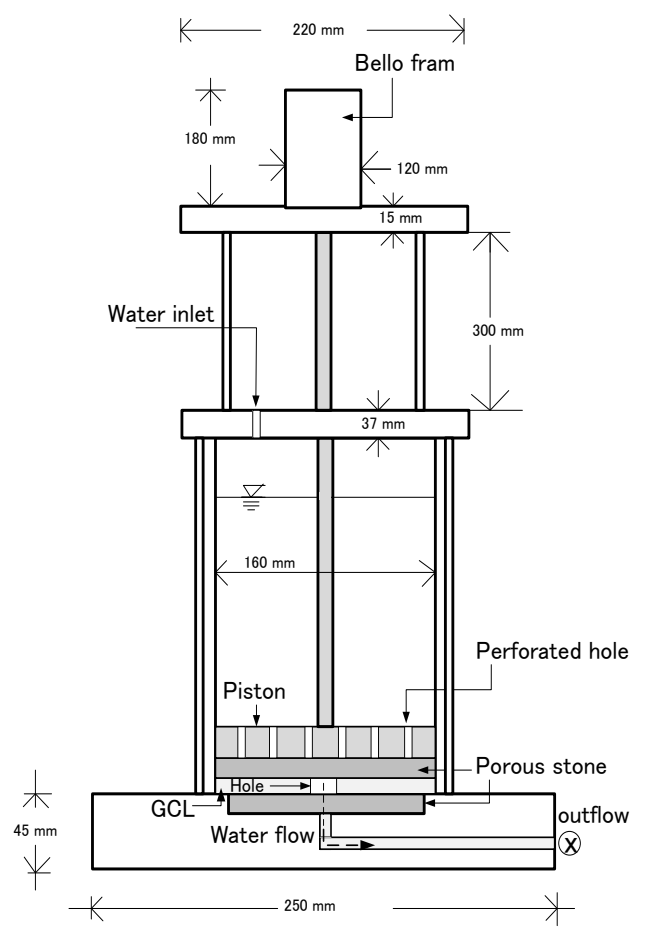

Fig. 3 Constant head leakage test

\section{(1) Equipment}

The sketch of the equipment for constant head test is shown in Fig. 3. The devices consist of:

(a) a transparent cylinder made of acrylic resin with an inner diameter of $150 \mathrm{~mm}$ (wall thickness of $5 \mathrm{~mm}$ ) and height of about $400 \mathrm{~mm}$;

(b) upper and lower pedestals made of stainless steel, and a porous stone with a diameter of about $120 \mathrm{~mm}$ is fixed at the top of the lower pedestal;

(c) a piston made of stainless steel, which is perforated with $3 \mathrm{~mm}$ diameter holes at $20 \mathrm{~mm}$ pitch to allow for drainage, and a ceramic porous stone with a diameter of $120 \mathrm{~mm}$ is inserted at the centre of the 
bottom of the piston; and

(d) a bello-fram fixed to the top of the upper pedestal for applying overburden pressure $(\sigma)$.

Sealing between the cylinder and the piston is achieved by a $4 \mathrm{~mm}$ diameter ' $\mathrm{O}$ ' ring lubricated with silicone grease and fixed around the piston.

A schematic description of the falling head test device is shown in Fig. 4. The main body of the device is made of copper, and consists of lower and upper parts. The lower part consists of a container with $150 \mathrm{~mm}$ inner diameter. A porous stone, $50 \mathrm{~mm}$ in diameter, is inserted at the center of the bottom of the container. The upper part of the device is a loading plate, $150 \mathrm{~mm}$ in diameter, with a porous stone, $120 \mathrm{~mm}$ in diameter, inserted at the center and in turn connected to a burette. The cross-sectional area of the burette is $200 \mathrm{~mm}^{2}$. For both the constant head and falling head tests, the overburden pressure can be applied is up to $200 \mathrm{kPa}$, and the GCL specimen can be tested is $150 \mathrm{~mm}$ in diameter.

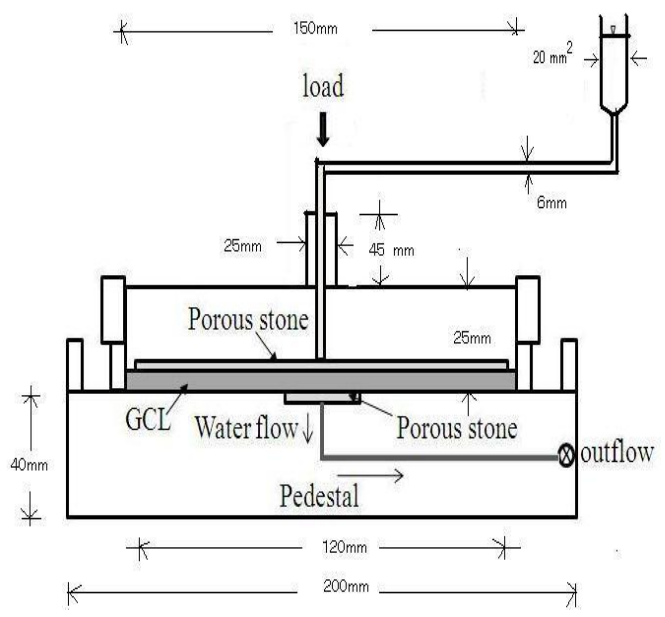

Fig. 4 Falling head leakage test

\section{(2) Test Procedures}

a) Preparation of GCL specimen

GCL specimens were cut into $150 \mathrm{~mm}$-diameter and make a hole of 30 or $40 \mathrm{~mm}$ in diameter in the center by a driller and/or cutter. For the GM-GCL, the GM side is glued to the piston (constant head test) or the loading plate (falling head test) on an annulus area along the outer periphery so as to prevent flow at GM/piston or GM/loading plate interface. Whereas for the GT-GCL, the sample is placed in the lower part of the device, then put paste of bentonite around the periphery of the sample to prevent leakage through the possible gap between the periphery of the specimen and the equipment.

b) Constant head leakage rate test

Install the piston (with GCL specimen attached in case of the GM-GCL) into the cylinder. Then install the loading system and apply desired pressure $(0$ or $200 \mathrm{kPa})$ and maintain for 1 hour. Pour liquid into the cylinder with a water head of $320 \mathrm{~mm}$ above the GCL specimen then start the test. Measure the outlet flow rate periodically until stable. The liquid is added periodically to maintain a constant water head.

c) Falling head test
Set up the test and apply the desired overburden pressure $(200 \mathrm{kPa})$ and maintain for 1 hour before start the leakage rate test. Set up water head of about 1000 $\mathrm{mm}$ on the top of the specimen through the burette. Open the valve for inlet flow and start the test; and record water level in the burette periodically. The test is continued until the calculated apparent hydraulic conductivity becomes stable.

\section{(3) Conditions investigated}

The result reported here is part of the results of a comprehensive investigation program on the self-healing capacity of GCL. The results of overburden pressure $(\sigma)$ and apparent permittivity $(\psi)$ of the damage holes with different size have been reported by Sari and Chai ${ }^{14)}$ already. In this study, the effect of the types of liquid is investigated mainly under the condition of diameter $(d)$ of a damage hole of $40 \mathrm{~mm}$ and $\sigma=0 \mathrm{kPa}$. To further consider the mutual effect of the types of liquid and $\sigma$ value, as well as referring the existing data reported by Sari and Chai ${ }^{14)}$, some tests were conducted under $d=30$ $\mathrm{mm}$ and $\sigma=200 \mathrm{kPa}$ conditions.

\section{Results and Discussion}

\section{(1) GM-GCL}

To quantify the liquid flow through the healed or partially healed damage hole, the apparent permittivity $(\psi)$ of the damage hole is defined as:

$$
\psi=\frac{Q}{A_{i} \Delta h}
$$

where $Q$ is the total flow rate, $A_{\mathrm{i}}$ is the initial area of damage hole, and $\Delta h$ is head difference above and below the GCL sample.

Permittivity $(\psi)$ versus elapsed time curves are given in Figs. 5(a) and (b) for $d=40 \mathrm{~mm}, \sigma=0 \mathrm{kPa}$ under constant head and $d=30 \mathrm{~mm}$ and $\sigma=200 \mathrm{kPa}$ under falling head conditions respectively. It can be seen that $\mathrm{CaCl}_{2}$ solution case resulted in the highest, and the ethanol solution the lowest $\psi$ value. The final $\psi$ value of $\mathrm{CaCl}_{2}$ case is almost 2 orders higher than that of the ethanol case. To further quantify the self-healing capacity, a parameter of area healing ratio $\left(\alpha_{h}\right)$ is defined as ${ }^{14)}$ :

$$
\alpha_{h}=\left(1-\frac{A_{f}}{A_{i}}\right) .100 \%
$$

where $A_{f}$ is the final unhealed area of a hole which can be measured after the test. For $d=40 \mathrm{~mm}$ and $\sigma=0$ and under constant head condition, the $\alpha_{h}$ values of using the tap-water, ethanol solution, $\mathrm{NaCl}$ and $\mathrm{CaCl}_{2}$ solutions are $88,90,60$ and $51 \%$ respectively. They are the same order as those of free swelling index (Table 2). Relatively the larger the free swelling index, the higher the $\alpha_{\mathrm{h}}$ value. Some photos of GCLs after the tests are shown in the Fig. 6.

The effect of types of liquid on the self-healing 
capacity of GCL can be explained by diffusive double layer (DDL) theory. According to Mitchell and Soga ${ }^{15}$, the thickness of DDL $(1 / K)$ is related to square root of dielectric constant, $D$, while $D$ is reversely related to electric conductivity, $E C(D \propto 1 / E C)$ of the solution, i.e. the larger the $E C$ value, the smaller the $1 / K$ value. In addition, the higher cation concentration and higher valence of cation, the smaller of the value of $1 / K$. A direct indication of $1 / K$ value may be the free swelling index, in which the value for $\mathrm{CaCl}_{2}$ is $9 \mathrm{~mL} / 2 \mathrm{~g}$, which is about $42 \%$ of the value for the tap-water case (Table 2). The thinner DDL means that under a given condition the bentonite will expand less, and leave a relative larger portion of a damage hole not being healed. The smaller $\psi$ value for the ethanol solution compared to the tap-water case may be due to the viscosity of the solution. Petrov et al. ${ }^{8)}$ reported that ethanol-water mixture with concentrations $<50 \%$ increased viscosity and decreased hydraulic conductivity of GCL.

Comparing the results in Figs. 5(a) and (b) indicates that the general tendency of the effect of the types of liquid is not changed by the overburden stress. Sari and Chai $^{14)}$ discussed that $\sigma$ value has two effects. One is squeezing hydrated bentonite into a damage hole, which can increase the self-healing capacity of a GCL. Other is to hinder hydration of the bentonite around a damage hole which may reduce the self-healing capacity. After the leakage rate test, the water contents of the bentonite expanded/squeezed into the hole, as well as around the hole were measured and the results are depicted in Fig. 7

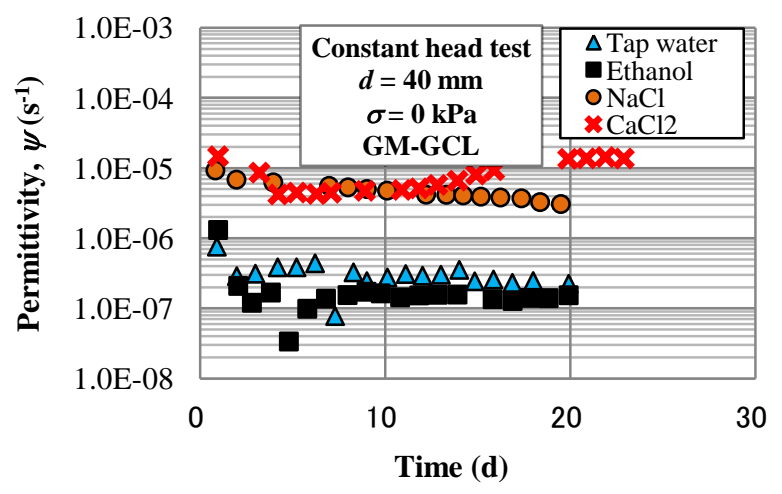

(a) Constant head test

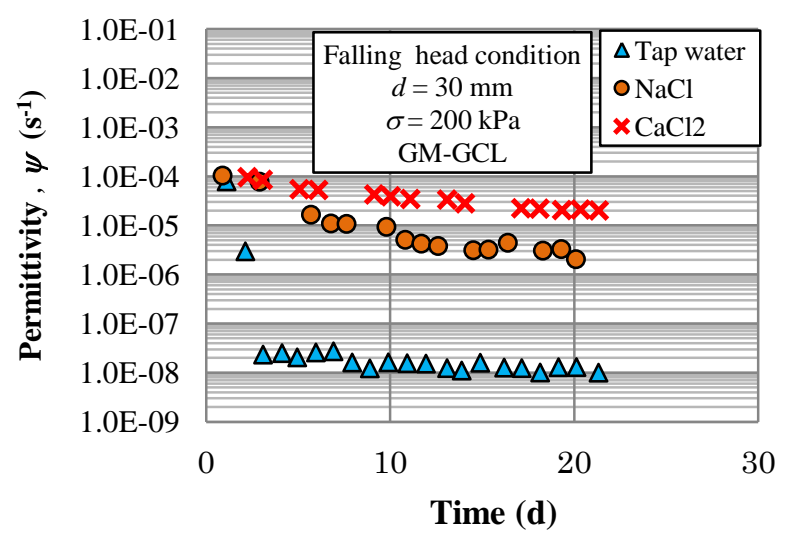

(b) Falling head test

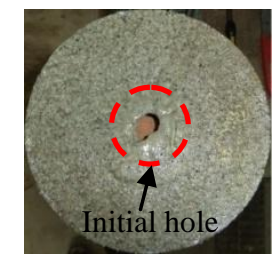

(a) Tap-water

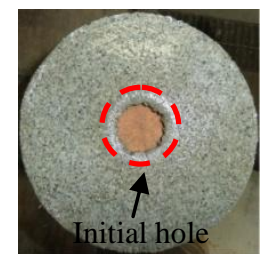

(b) $\mathrm{NaCl}$ solution

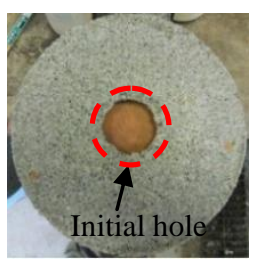

(c) $\mathrm{CaCl}_{2}$ solution

Fig. 6 Photos of GM-GCL after test for Constant head test

for $d=40 \mathrm{~mm}, \sigma=0 \mathrm{kPa}$ cases (constant head), and in Fig. 8 for $d=30 \mathrm{~mm}, \sigma=200 \mathrm{kPa}$ cases (falling head) respectively. The dashed lines in the figures just provide a guide for getting a picture of water content variation pattern. Note: the measured water content of the bentonite in a hole is plotted at the center of the hole for convenience, and it does not mean the sample is from the center of the hole. It can be seen that increase $\sigma$ value reduced water content of the bentonite in and around the hole, and it also reduced the difference of water content between different types of liquid. For the water content of the bentonite in the hole, in the case of the tap-water, it reduced from about $500 \%$ to about $190 \%$ when $\sigma$ increased from 0 to $200 \mathrm{kPa}$. While for $\mathrm{CaCl}_{2}$ solution case, it did not change much. This tendency implies that increase $\sigma$ value may reduce the degree of the effect of types of liquid. However, for using the tap-water and under $\sigma=0$ and $200 \mathrm{kPa}$ cases, the thicknesses of the bentonite in the samples after the test were about $8 \mathrm{~mm}$ and $4 \mathrm{~mm}$ respectively. This means that increase $\sigma$ value will reduce the volume of the damage hole which needs to be filled by the bentonite expanded and/or squeezed into the hole. Furthermore, increase $\sigma$ value can enhance the squeezing effect. $S_{\text {u }}$ value can influence the squeezing effect. For $\sigma=0$, the water contents of the

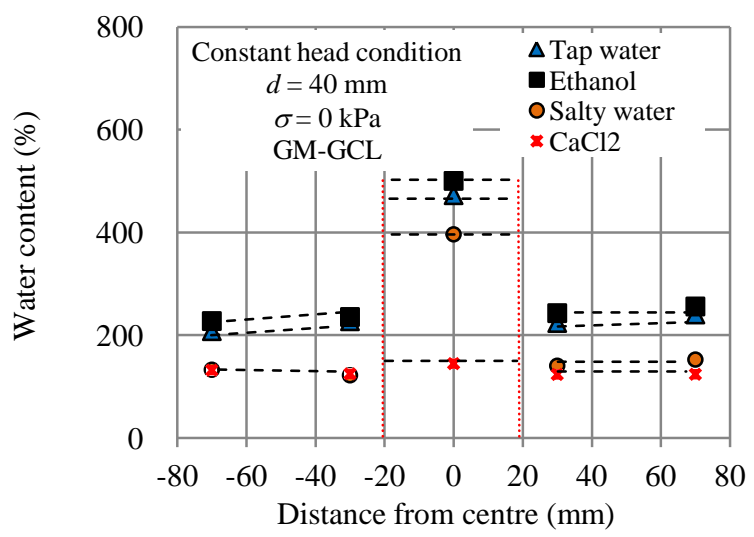

Fig. 7 Water content of bentonite after Constant head test

Fig. 5 Permittivity versus elapsed time 


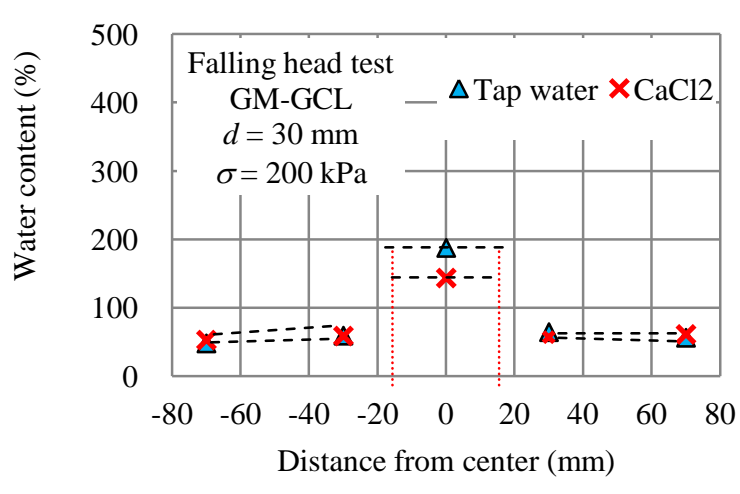

Fig. 8 Water content of bentonite after Falling head test

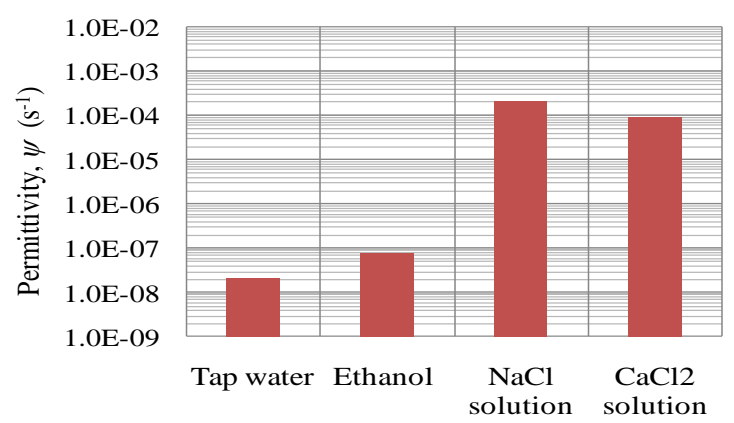

Fig. 9 Permittivity of GT-GCL for different type of liquid

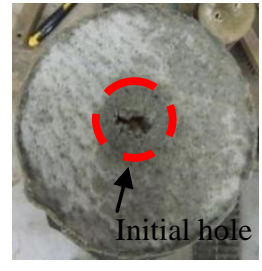

(a) Tap-water

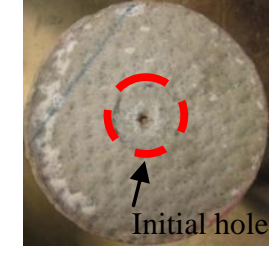

(b) Ethanol

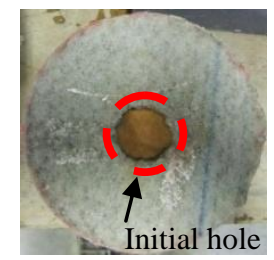

(c) $\mathrm{NaCl}$ solution

Fig. 10 Photos of GT-GCL after test

bentonite around the hole are about $120 \%$ for the $\mathrm{NaCl}$ and $\mathrm{CaCl}_{2}$ solutions and about $220 \%$ for the tap-water and ethanol solution, respectively. From the results in Fig. $2, S_{\mathrm{u}}$ values for about $220 \%$ (extrapolating) of the tap water and about $120 \%$ of the $\mathrm{NaCl}$ solution are about the same.

\section{(2) GT-GCL}

Unlike GM-GCL, for GT-GCL, the liquid can flow through the undamaged area also even the flow rate may be very small. To investigate the effect of the types of liquid on self-healing capacity, the flow rate $\left(Q_{h}\right)$ through the hole of GT-GCLs is defined as follows:

$$
Q_{h}=Q-Q_{\text {int }}
$$

where $Q_{\text {int }}$ is the flow rate through the intact part of a specimen. $Q_{i n t}$ value can be measured by the flow rate tests using the intact sample. Using Eq. (3) and considering the steady state condition, $\psi$ values for four different liquids are compared in Fig. 9. It can be seen that $\psi$ values of the $\mathrm{NaCl}$ and $\mathrm{CaCl}_{2}$ cases are more than 4 and 3 orders higher than that of the tap-water case. The degree of the effect of the types of liquid is more than that of the GM-GCL, and it may due to the different structure of the GT-GCL compared to the GM-GCL.

Some photos of the GT-GCL samples after leakage rate tests are shown in Fig. 10. They are similar with those of GM-GCL in Fig. 6. The area healing rates $\left(\alpha_{h}\right)$ are $93 \%, 99 \%$ and $51 \%$ for the tap-water, ethanol solution and $\mathrm{NaCl}$ solution respectively.

The water contents of the bentonite in the healed area in the hole and surrounding area of GT-GCL samples tested were measured and shown in the Fig. 11. The values are comparable with that of GM-GCL (Fig. 7), but little bit lower. It is considered may be due to some restriction from the needle punched fibers connecting two layers of the geotextiles in the GT-GCL. The bentonite in the GT-GCL specimen was obtained by cutting sub-sample from the GT-GCL specimen at appropriate locations and then separated the bentonite and geotextiles of the sub-samples.

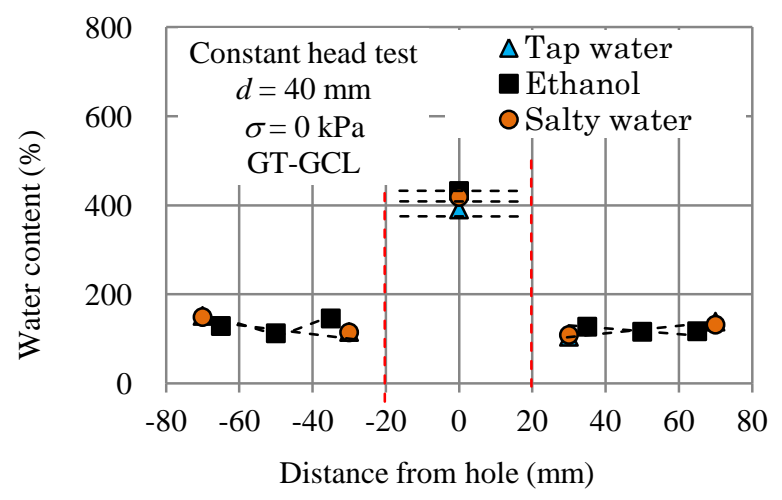

Fig. 11 Water content of bentonite in GT-GCLs after test

\section{Conclusions}

The effect of types of liquid on self-healing capacity of the geosynthetic clay liners (GCLs) has been investigated by laboratory leakage rate tests. Four types of liquid, namely, tap-water, $10 \mathrm{~g} / \mathrm{l} \mathrm{NaCl}$ solution, $100 \mathrm{ml} / \mathrm{l}$ ethanol solution and $11.1 \mathrm{~g} / \mathrm{l} \mathrm{CaCl}_{2}$ solution were used. Based on the test results, following conclusions can be drawn.

(1) Types of liquid have a significant effect on self-healing capacity of both geomembrane support GCL (GM-GCL) and geotextile encased GCL (GT-GCL). The mechanism of the influence is due to different thickness of diffusive double layer (DDL) formed around bentonite particles inside GCLs. The thicker of DDL, the higher the self-healing capacity. Free swelling index of the bentonite with the corresponding liquid can be used to evaluate the relative effect. 
(2) For the conditions investigated, it seems that increase overburden pressure $(\sigma)$ did not change the general tendency of the effect of the types of liquid. Increasing $\sigma$ value can enhance the squeezing effect, and it tends to increase self-healing capacity of GCL, but it also can restrict the amount of the expansion of the bentonite due to hydration which intends to reduce the self-healing capacity of GCL.

The practical implication of the results from this study is that for design a landfill liner system, if the possible leachates will be enrich of cations, the self-healing capacity of GCLs will be limited and composite liner systems may be used.

\section{Acknowledgement}

The GCLs tested were provided by Mr. M. Mizuno at Hojo. Co. Ltd, Japan. Mr. A. Saito at Saga University, Japan provided technical support for conducting the tests reported in this paper.

\section{Reference}

1) Bouazza, A.: Geosynthetic clay liners. Geotextiles and Geomembranes, Vol. 20, No.1, pp. 3-17, 2002.

2) Bouazza, A., and Bowders, J. J.: Geosynthetic clay liners for waste containment facilities, CRC Press/Balkema, Leiden, Netherlands, 2010.

3) Touze-Foltz, N., Lupo, J. and Barosso, M.: Geoenvironmental applications of geosynthetics. In: Keynote Lecture, Proceedings EuroGeo4. 98 p., 2008.

4) Shackelford, C. D., Sevick, G. W. and Eykholt, G. R.: Hydraulic conductivity of geosynthetic clay liners to tailings impoundment solutions. Geotextiles and Geomembranes, Vol. 28, pp. 149-162, 2010.

5) Nosko, V. and Touze-Foltz, N.: Geomembrane liner failures: modeling of its influence on contaminant transfer. Proceedings on the second European Conference on Geosynthetics2, Bologna, Italy, pp. 557-560, 2000.

6) Egloffstein, T. A.: Natural bentonites-influence of the ion exchange and partial desiccation on permeability and self-healing capacity of bentonites used in GCLs. Geotextiles and Geomembranes, Vol. 19, pp. 427-444, 2001.

7) Katsumi, T., Ishimori, H., Onikatta, M. and Fukagawa, R.: Long-term barrier performance of modified bentonite materials against sodium and calcium permeant solutions. Geotextiles and Geomembranes, Vol. 26, pp. 14-30, 2008.

8) Petrov, R, J. and Rowe, R. K.: Geosynthetic clay liner-chemical compatibility by hydraulic conductivity testing and factors impacting its performance. Canadian Geotechnical Journal, Vol. 34, No. 6, pp. 863 - 885, 1997.

9) Jo, H., Katsumi, T., Benson, C. and Edil, T.: Hydraulic conductivity and swelling of nonprehydrated GCLs permeated with single-species salt solutions. Journal of Geotechnical and Geoenvironmental Engineering, ASCE, Vol. 127, No. 7, pp. 557-567, 2001.

10)Ishimori, H. and Katsumi, T.: Temperature effects on the swelling capacity and barrier performance of geosynthetic clay liners permeated with sodium chloride solutions. Geotextiles and Geomembranes, Vol. 33, pp. 25-33, 2012.

11)Rosin-Paumier, S. and Touze-Foltz, N.: Hydraulic and chemical evolution of GCLs during filter press and oedopermeatric tests performed with real leachate. Geotextiles and Geomembranes, Vol. 33, pp. 15-24, 2012.

12)Rosin-Paumier, S. and Touze-Foltz, N., Pantet, A.: Impact of a synthetic leachate on permittivity of GCLs measured by filter press and oedometer tests. Geotextiles and Geomembranes, Vol. 29, pp. 211-221, 2011.

13)Takahashi, S. and Kondo, M.: Permeability of a geomembrane-supported geosynthetic clay liner with damaged part. Geosynthetics Engineering Journal, Vol. 14, pp. 350 - 359, 1999. (in Japanese)

14)Sari, K. and Chai, J.-C.: Self-healing capacity of geosynthetic clay liners and influencing factors. Geotextiles and Geomembranes, 2013. dx.doi.org/10.1016/j.geotexmem.2013.08.006

15)Mitchell, J. K. and Soga, K.: Fundamentals of soils behavior. John Wiley \& Sons, Inc., Hoboken, New Jersey, USA, 2005.

\title{
GCL の自己修復能力における滲出溶液の性質の影響に関する研究
}

\section{柴 錦春・Kartika Sari - 日野剛徳}

\begin{abstract}
ジオシンセティックスクレイライナー (GCLs) の自己修復能力に対して、溶液の性質（種類） の影響を室内漏水試験により検討した。用いた 4 種類の溶液は、水道水、 $10 \mathrm{~g} / \ell の ~ \mathrm{NaCl}$ 溶液、 $100 \mathrm{mg} / \ell$ のエタノールおよび $11.1 \mathrm{~g} / \ell$ の $\mathrm{CaCl}_{2}$ 溶液である。試験の結果によれば、溶液の性質は GCL 中のベントナイトの膨潤量に影響を与えるによって、GCL の自己修復能力を大きく左右す る。また、ベントナイトの自由膨潤量は、GCLの自己修復能力における溶液性質の影響の程度 を評価する指標として用いることができる。さらに、試験した条件で、上載圧力の増加に伴う溶 液性質の影響の傾向に変化が認められないことがわかった。
\end{abstract}

キーワード：ジオシンセティックスクレイライナー、自己修復能力、漏水試験、溶液、廃棄物処 分場ライナー 